\title{
Pantoea stewartii subsp. stewartii Exhibits Surface Motility, Which is a Critical Aspect of Stewart's Wilt Disease Development on Maize
}

\author{
Carmen M. Herrera, ${ }^{1}$ Maria D. Koutsoudis, ${ }^{2}$ Xiaolei Wang,,${ }^{1}$ and Susanne B. von Bodman ${ }^{1,2}$ \\ ${ }^{1}$ Department of Plant Science and ${ }^{2}$ Department of Molecular and Cell Biology, University of Connecticut, Storrs 06269, \\ U.S.A.
}

Submitted 4 April 2008. Accepted 18 June 2008.

\begin{abstract}
Pantoea stewartii subsp. stewartii is a plant-pathogenic bacterium that causes Stewart's vascular wilt in maize. The organism is taxonomically described as aflagellated and nonmotile. We recently showed that $P$. stewartii colonizes the xylem of maize as sessile, cell-wall-adherent biofilms. Biofilm formation is a developmental process that generally involves some form of surface motility. For that reason, we reexamined the motility properties of $P$. stewartii DC283 based on the assumption that the organism requires some form of surface motility for biofilm development. Here, we show that the organism is highly motile on agar surfaces. This motility is flagella dependent, shown by the fact that a fliC mutant, impaired in flagellin subunit synthesis, is nonmotile. Motility also requires the production of stewartan exopolysaccharide. Moreover, surface motility plays a significant role in the colonization of the plant host.
\end{abstract}

Additional keywords: Erwinia stewartii, EsaI/EsaR, virulence, xylem dissemination.

Pantoea stewartii subsp. stewartii (Mergaert et al. 1993) (syn. Erwinia stewartii (Smith 1898)) is a gram-negative bacterium that is historically described as aflagellated and nonmotile (Pepper 1967). It is the causal agent of Stewart's vascular wilt and leaf blight on susceptible maize cultivars. Bacterial transmission in the field requires the feeding action of the pathogenbearing corn flea beetle, Chaetocnema pulicaria, which serves as overwintering host for P. stewartii (Pataky 2003). Stewart's wilt disease is characterized by two distinct phases of symptomology. Water-soaked lesions develop during early infection when the bacteria reside in the intercellular spaces of leaves after deposition by the beetle. This symptomology relies on functions encoded by the hypersensitive response and pathogenicity ( $h r p$ ) type III secretion system (Frederick et al. 2001) and the genetically linked disease-specific effector locus wts ( $d s p$ ) (Ham et al. 2006). Subsequently, the bacteria colonize the xylem of maize. Here, the bacteria grow to very high cell densities and secrete an abundance of the anionic stewartan exopolysaccharide (EPS). These conditions impede the free flow of xylem fluid, leading to vascular collapse and plant wilt (Braun 1982; Dolph et al. 1988; Nimtz et al. 1996; Pataky 2003). Stewartan EPS is a major virulence factor for P. stewartii. Mutants that do not produce EPS fail to induce wilt.

Corresponding author: S. B. von Bodman; Telephone +1.860.486.4408; Fax: +1.860.486.0534; E-mail: susanne.vonbodman@uconn.edu
We showed that stewartan EPS synthesis is a cell-densitydependent phenotype controlled by the EsaI/EsaR quorumsensing (QS) system (Beck von Bodman and Farrand 1995; von Bodman et al. 1998, 2003). At low cell density or in the absence of the acyl-homoserine lactone (AHL) QS signal, EsaR functions as a repressor of the $r \operatorname{cs} A$ gene. RcsA is an essential component of the RcsA/RcsB activation complex (Carlier and von Bodman 2006; Majdalani and Gottesman 2005; Minogue et al. 2002, 2005). Inducing levels of AHL alleviate EsaR repression of $r \operatorname{cs} A$, leading to $\mathrm{RcsA} / \mathrm{RcsB}$ transcription complex formation and stimulated expression of the EPS biosynthetic locus (Bernhard et al. 1993; Carlier and von Bodman 2006). Disruption of the esaR gene gives rise to mutants that constitutively synthesize stewartan. Surprisingly, these strains are also severely attenuated in their ability to induce Stewart's wilt disease, even though they produce excessive levels of the EPS virulence factor (Koutsoudis et al. 2006; von Bodman et al. 1998). The logical explanation for these observations is that the bacteria require a mostly EPS-free state to perform functions, such as surface adhesion, typical of low-celldensity populations. Correspondingly, growth-phase-dependent EPS synthesis promotes the further development and maturation of the multicellular community structure. This logic is supported by numerous studies showing that spatiotemporal or growthphase-dependent gene expression is a fundamental aspect of bacterial biofilm development and multicellular bacterial existence in nature (Beloin and Ghigo 2004; Hall-Stoodley and Stoodley 2005; Hall-Stoodley et al. 2004; Parsek and Greenberg 2000; Sauer et al. 2002; Whiteley et al. 2001). Frequently, these developmentally keyed attributes are also significant factors of bacterial pathogenicity or survival in nature (Danhorn and Fuqua 2007; Fuqua et al. 2001; Hammer and Bassler 2003; Quinones et al. 2005; Schembri et al. 2004; Wang et al. 2006).

The ability of bacteria to translocate over surfaces is an integral part of bacterial biofilm differentiation. There are different types of bacterial motility (Harshey 2003). Swarming motility is a flagella-dependent form of social migration over semisolid surfaces typically involving elongated, hyperflagellated cells (Harshey 2003). It is often an essential early step in the biofilm differentiation process, during which bacteria consolidate to form aggregates or microcolonies (Monier and Lindow 2003; O'Toole and Kolter 1998; Ramsey and Whiteley 2004). Flagella-dependent motility is also important during the dispersal phase of biofilm formation, when a subpopulation of bacteria reenter the planktonic stage in an effort to seek new sites of colonization (Danhorn and Fuqua 2007; Ramey and Whiteley 2004; Dow et al. 2003). Therefore, it is not surprising that motility contributes significantly to the pathogenic fitness of nu- 
merous well-studied bacterial pathogens (An et al. 2006; Gardel and Mekalanos 1996; Mattick 2002; O'Toole and Kolter 1998). In the case of plant pathogenic bacteria, the original studies by Ries and collaborators demonstrated that motility plays a significant role in Pseudomonas syringae pv. glycinea and Erwinia amylovora virulence (Bayot and Ries 1986; Hatterman and Ries 1989). Ralstonia solanacearum requires twitching motility and flagella-driven aerotaxis for full pathogenic fitness (Kang et al. 2002; Tans-Kersten et al. 2001; Yao and Allen 2007). Flagella-driven motility in Burkholderia glumae is an important factor in the cause of rice grain rot presumably enabling the bacteria to move toward infection sites within the flowers of rice (Kim et al. 2007). Motility plays a role also in the infection biology of Agrobacterium spp. (Merritt et al. 2007) and is important for the establishment of successful symbiotic plant-microbe relationships (Bohm et al. 2007; Braeken et al. 2007; Fujishige et al. 2006).

We postulated that Pantoea stewartii might have retained the ability to translocate over surfaces during biofilm development. This prediction was supported by the presence of highly conserved flagellar and motility (fli, flg, flh, and mot) gene systems in the genome sequence of $P$. stewartii (Glasner et al. 2003, 2006). Here, we report that $P$. stewartii exhibits robust flagella-dependent surface motility when grown on semisolid agar but lacks the ability to swim under planktonic conditions or when examined in low-percentage swimming assays. P. stew- artii surface motility depends also on the controlled synthesis of stewartan EPS. Our data further indicated that surface motility in P. stewartii promotes microcolony formation and is important for host colonization and pathogenic fitness.

\section{RESULTS}

\section{Macroscopic characteristics} of $P$. stewartii surface colonization.

As a first step toward verifying that $P$. stewartii is able to translocate over solid surfaces, we transferred a cell suspension of approximately $10^{7}$ cells of the wild-type strain DC283 to the center of a semisolid swarming agar plate. After $5 \mathrm{~h}$ of incubation, the bacteria developed into compact, round colonies exhibiting the first signs of spatial organization at the periphery of the colony (Fig. 1A). After $10 \mathrm{~h}$, the bacterial colony developed an elaborate, seemingly three-dimensional palisade-like ring structure that appeared to be composed of densely populated cells (M. D. Koutsoudis, unpublished observations). This ring structure was surrounded by a mucoid or slime-encased bacterial layer (Fig. 1B). After $16 \mathrm{~h}$ of incubation, the ring ruptured on one side, presumably by mass action pressure of cells that had transitioned into a vigorous motility mode (Fig. 1C and D). The site at which the ring opened appeared to signify the directionality of bacterial movement and subsequent rapid unidirectional colony expansion. Mechanical
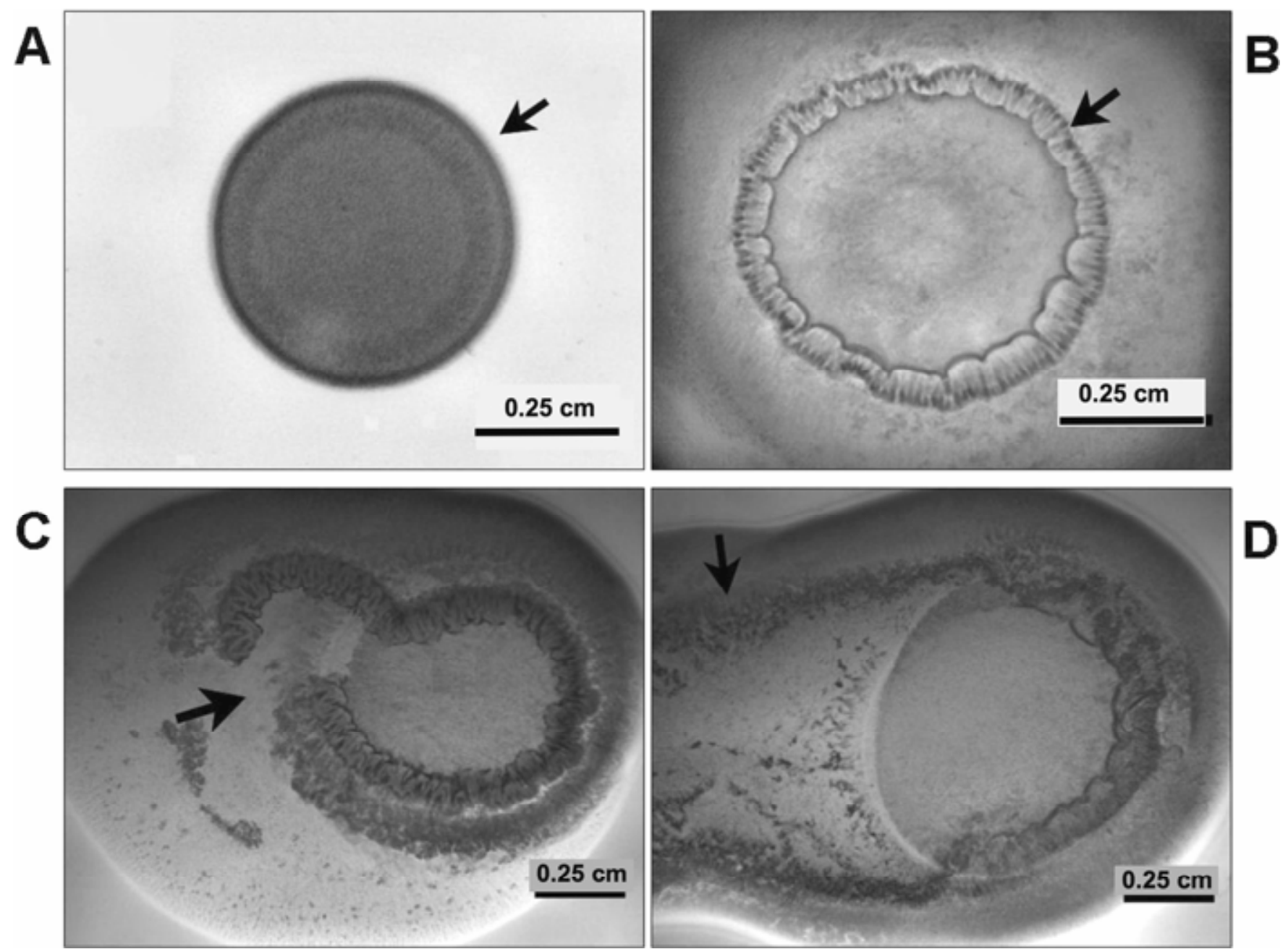

Fig. 1. Different phases of surface motility on swarming medium by the wild-type strain DC283. An inoculum of approximately $10^{7} \mathrm{CFU}$ was spot inoculated in the center of a swarming agar (nutrient broth, $0.4 \%$ agar, $0.4 \%$ glucose) plate and incubated at $28^{\circ} \mathrm{C}$. A, Cells after $5 \mathrm{~h}$ of incubation showing the first signs of peripheral colony organization (arrow); B, palisade-like ring differentiation (arrow) after $10 \mathrm{~h}$; C, ring rupture (arrow) $16 \mathrm{~h}$ postinoculation; $\mathbf{D}$, rapid surface colonization after $30 \mathrm{~h}$. 
ring rupture elsewhere proved insufficient to trigger bacterial movement in a different direction (data not shown). This characteristic developmental behavior appeared highly consistent; in fact, placing multiple inocula on the same agar plate developed the identical ring pattern, followed by ring rupture and parallel unidirectional movement (data not shown). We tested multiple factors to gain a better understanding of this directional movement and found that even the slightest incline of the swarming agar plate promotes movement in the direction of the downward slope (data not shown). The unidirectional surface motility behavior is quite distinct from the radial or concentric expansion pattern characteristic of other bacteria (Eberl et al. 1999; Harshey and Matsuyama 1994; McCarter 2001; Rauprich et al. 1996). Here, it is important to note that mutants such as ES $\Delta I R$, which produce normal amounts of EPS, fail to engage in unidirectional movement, arguing against passive sliding in the direction of a downward slope.

\section{Transition to vigorous motility appears}

\section{to respond to external or intrinsic cues.}

The localized transition into the vigorous, unidirectional motility may be initiated by spontaneous mutagenesis, phase variation, or specific environmental or physiological cues. To begin to address this question, we removed cells from different areas of the swarmer colony to assay their behavior when placed onto fresh semisolid agar medium. The direct transfer of cells taken from the ring or center of the colony induced normal colony development typified by ring formation, ring rupture, and unidirectional movement. In contrast, cells derived from the vigorous motility region, outside the ring structure, continued in the expansive motility mode (no ring differentiation) when placed onto fresh medium. Resuspension of such vigorously motile cells in phosphate-buffered saline (PBS) buffer or subculture in liquid medium prior to transfer to fresh medium led to normal swarming colony morphogenesis (data not shown). These observations suggest that vigorous motility can be reset, which argues against spontaneous mutations or phase variation as a switching mechanism.

\section{Medium conditions that promote or inhibit swarming surface motility.}

The addition of an energy-rich carbon source is essential for swarming surface motility (Harshey and Matsuyama 1994; Kim and Surette 2005). Among the carbon sources tested, growth on glucose induced the most robust surface motility response, with sucrose, a phosphoenolpyruvate phosphotransferase system (PTS) sugar, and galactose, a non-PTS sugar, supporting intermediate levels of motility. Mannitol, another PTS sugar, failed to support swarming, as did lactose and glycerol, which are two non-PTS sugars. Media rich in potassium and sodium ions were also inhibitory to $P$. stewartii surface motility. However, addition of phenamil, a sodium-channelblocking drug that blocks polar flagellum rotation in Vibrio parahaemolyticus and correspondingly stimulates lateral flagella surface motility (Boles and McCarter 2000), failed to counteract the sodium- and potassium-sensitive motility phenotype in $P$. stewartii. (data not shown). Inclusion of the carbonyl cyanide 3-chlorophenylhydrazone (CCCP) proton ionophore abrogated $P$. stewartii swarming motility.

\section{The role of QS in swarming motility.}

Stewartan EPS synthesis is governed by QS regulation, and the cell-density-dependent control of EPS is a key factor in biofilm development (Koutsoudis et al. 2006). Here, we evaluated the role of QS in swarming surface motility. Normal unidirectional motility characteristic of the wild-type strain DC283 after placing the bacterial inoculum in the center of an agar plate is shown in Figure 2A. The esaI mutant strain ESN51, which lacks the ability to synthesize the AHL autoinducer and EPS, was deficient in swarming motility (Fig. 2B). Addition of exogenous AHL restored swarming motility (Fig. 2C) to near wild-type levels. Most interestingly, the mutant strain ES $\triangle I R$, which is derepressed for EPS synthesis, was attenuated for swarming and failed to differentiate a pronounced ring structure (Fig. 2D).

\section{P. stewartii surface motility is $\mathrm{fliC}_{I}$ dependent.}

The nearly complete genome sequence for $P$. stewartii DC283 revealed conserved $f l i, f l g$, and $f l h$ gene systems. In particular, the genome harbors several full-length and partial open reading frames (ORF), with sequences homologous to fliC genes. These genes generally encode the major structural components for flagella synthesis in Escherichia coli, Salmonella spp., and many other bacteria. One of these ORF, which we designated $f l i C_{I}$, was of particular interest because of its genetic linkage and syntenous organization to the related flagellar fliT, fliS, fliD, and $f_{l i C}$ gene system in E. coli and Salmonella spp. (Fig. 3A). The promoter of fliC $_{I}$ featured a $\sigma^{28}$ signature regulatory sequence suggesting a transcriptional hierarchy typical of flagellar gene systems (Chilcott and Hughes 2000). The $P$. stewartii fli $C_{I}$ encodes a predicted protein of 309 amino acids (aa), which is considerably smaller than the corresponding 494 aa FliC phase1 flagellin protein of the Salmonella typhimurium (Malapaka et al. 2007). Sequence alignment shows

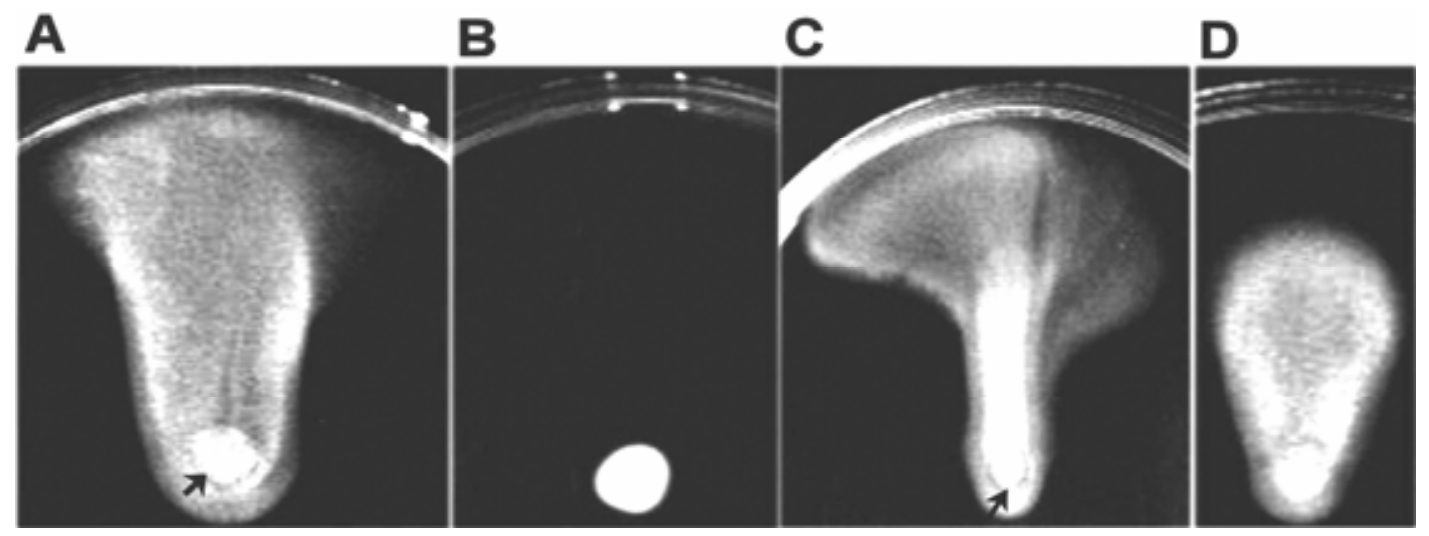

Fig. 2. Quorum sensing (QS) regulation of surface motility. A, Wild type strain DC283 exhibits normal swarming colony development with a pronounced ring structure (arrow) and unidirectional rigorous movement; B, QS mutant ESN51 (esaI::Tn5) is motility impaired in the absence of exogenous acyl-homoserine lactone (AHL) but $\mathbf{C}$, exhibits normal motility when grown in presence of $10 \mu \mathrm{M}$ AHL. D, QS mutant ES $\Delta \mathrm{IR}(\Delta e s a I-e s a R)$ strain exhibits intermediary motility and appears to lack a pronounced ring structure and unidirectional movement. 
that both proteins feature highly conserved $\mathrm{N}$-terminal and $\mathrm{C}$ terminal domains but differ in the extent and composition of the internal, hypervariant domain structure (Fig. 3B) (Malapaka et al. 2007). We mutagenized the $f l i C_{I}$ gene by replacing most of its coding region with a gentamicin antibiotic resistance cassette and transferred the mutant allele into the wild-type DC283 genome by allelic replacement. The resulting mutant strain, PNSS40, was unable to transition into the vigorous motility phase when assayed on semisolid medium (Fig. 4). In contrast, the mutant strain expressing the wild-type fli $_{I}$ gene from plasmid pCH5 (data not shown) or the his $s_{6}-f l i C$ fusion gene carried on plasmid pCH7 restored motility (Fig. 4).

The his $_{6}-f_{l i C_{I}}$ complemented strain was used to demonstrate His $_{6}-$ FliC $_{\mathrm{I}}$ secretion into the extracellular fraction of swarmer cells grown on semisolid medium. His $_{6}$-tag antibody-specific Western blot analysis of total protein recovered from the extracellular fraction separated by sodium dodecyl sulfate polyacrylamide gel electrophoresis (SDS-PAGE) detected a single protein band that co-migrated with the affinity-purified $\mathrm{His}_{6}{ }^{-}$ $\mathrm{FliC}_{\mathrm{I}}$ protein (predicted molecular mass of 35.6. kDa) (Fig. 4). These data together provide strong support for $\mathrm{fli}_{I}$-specific flagellar assembly and function in $P$. stewartii cells grown on semisolid agar surfaces.

\section{Visualization of flagella}

by transmission electron microscopy.

Final confirmation of flagella-mediated motility required examination of the wild-type $P$. stewartii DC283, the $\Delta f l i C_{I}$ mutant PNSS40, and the fli $_{T^{-}}$-complemented strain PNSS41 by transmission electron microscopy (TEM). Samples were taken from the edge of the respective colonies grown on semisolid medium and prepared for negative staining and TEM imaging (Fig. 5A, inset left corner). As can be seen in Figure $5 \mathrm{~A}$, wild-type cells contained several long, flagella-like appendages. The $\Delta f l i C_{I}$ mutant cells lacked any evidence of flagellar filaments (Fig. 5D), whereas the complemented strain PNSS41
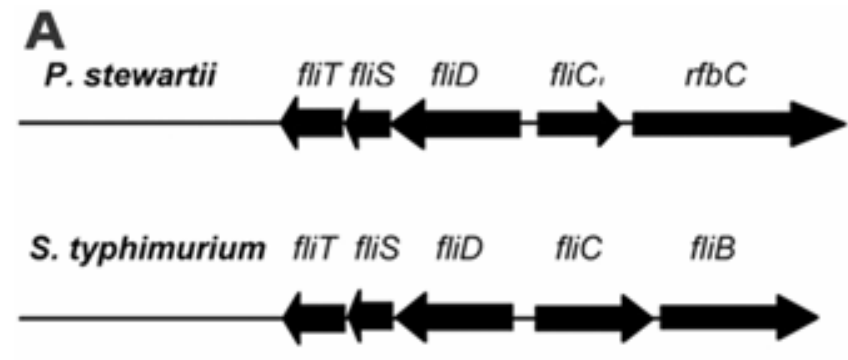

\section{S. typhimurium FliC flagellin}

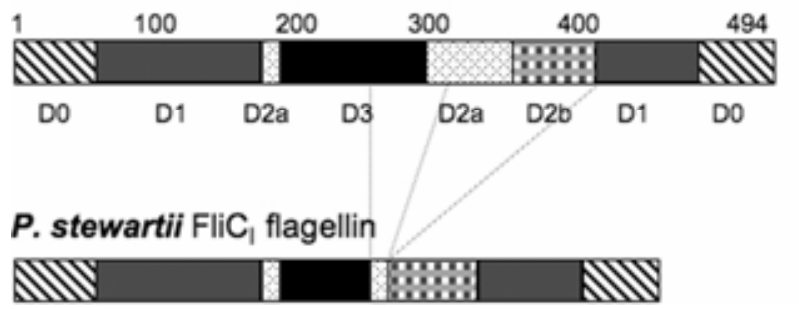

Fig. 3. A, Genetic organization of fliTSDC $C_{1}$ locus of Pantoea stewartii is identical to that of Salmonella typhimurium except that the gene downstream of $f l i C$ is $r f b C$ in $P$. stewartii and fliB in $S$. typhimurium (note: fliB has no apparent role in motility) (Frye et al. 2006). B, Domain comparison of the FliC of $S$. typhimurium according to Malapaka and associates (2007) and $\mathrm{FliC}_{1}$ of $P$. stewartii. The $P$. stewartii $\mathrm{FliC}_{1}$ protein (309 amino acids [aa]) lacks much of the internal hypervariable domain structure present in the multidomain $S$. typhimurium flagellin protein (469 aa) but retains the functionally essential $\mathrm{N}$ - and $\mathrm{C}$-terminal domains.
(Fig. 5C) produced flagella similar to the wild-type strain. The single bacterial cell depicted in Figure 5B shows two lateral flagella emerging from the cell surface. Interestingly, the cells taken from the edge of the swarmer colony comprised a mixed population of flagellated and elongated nonflagellated cells as well as a number of small, dividing cells (Fig. 5E).

\section{Swarming motility contributes to microcolony formation.}

The motility assay depicted in Figure 1 involves a large number of cells that give rise to localized confluent growth at the center of the agar surface. We repeated these assays with a diluted inoculum to give rise to discrete, but reasonably spaced small colonies. The cells were green fluorescent protein (GFP) tagged to allow visualization of even minute colonies by fluorescence microscopy (Fig. 6A). After $24 \mathrm{~h}$ of growth, bacteria co-migrated between adjacent colonies (Fig. 6B, arrow), leading to the formation of larger aggregates (Fig. 6C). In contrast, the QS mutant strain ESN51-GFP, which is impaired in stewartan EPS synthesis for lack of AHL production (Fig. 6D), and the $\Delta f l i C_{I}$ mutant strain PNSS40-GFP were unable to coalesce, with each colony remaining a discrete unit and lacking any sign of intercolony migration (Fig. 6E). However, the expression of a functional copy of fliC $_{I}$ in PNSS41-GFP restored intercolony migration and aggregate formation (Fig. 6F), as did strain ESN51-GFP grown in the presence of AHL (data not shown). These data show that EPS synthesis and $\mathrm{FliC}_{\mathrm{I}}$-dependent surface motility are core requirements for aggregate or microcolony formation. Additional features to note are, first, the presence of brightly fluorescent, dense ring structures in each member colony that were still discernible within the larger aggregates (Fig. 6C). These structures resemble the ring structure of the macrocolony depicted in Figure 1. Additionally, the $\Delta f l i C_{I}$ mutant strain differentiated into strongly fluorescent spoke-like structures, presumably also composed of densely packed bacterial cells.

\section{Flagella-mediated surface motility plays a role in xylem colonization.}

$P$. stewartii colonizes seedling leaves primarily in a basipetal direction (Koutsoudis et al. 2006). To examine the potential role of $\mathrm{fliC}_{I^{-}}$-mediated flagellar motility in xylem colonization,

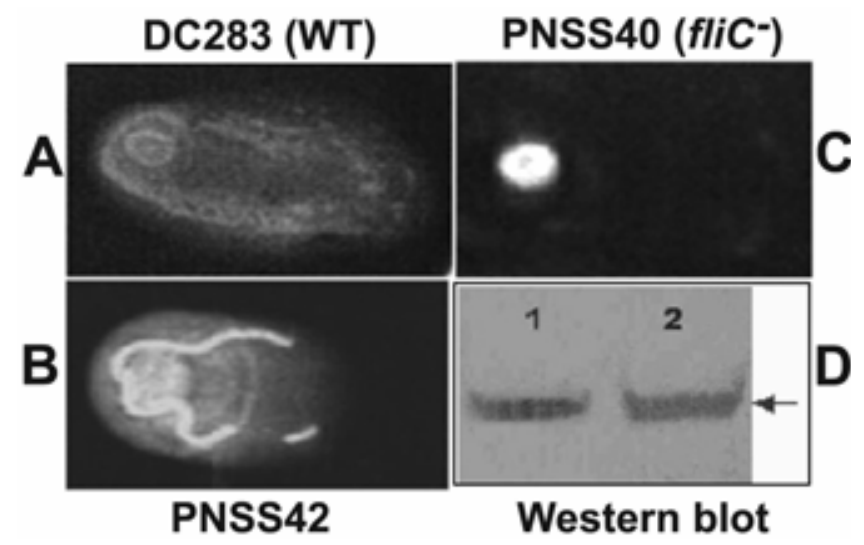

Fig. 4. FliC $_{1}$ is essential for Pantoea stewartii surface motility. A, Wildtype strain DC283 observed after $24 \mathrm{~h}$ of incubation exhibits normal swarming colony development and motility compared with $\mathbf{B}$, the $f l i C_{I}$ deletion mutant strain PNSS40 that is nonmotile. C, The his $s_{6}-f_{i l} C_{I^{-}}$ complemented strain PNSS42 recovers swarming motility; not shown is the wild-type $f_{l i C} C$-complemented strain PNSS41, which also restores motility. E, Western blot showing that $\mathrm{His}_{6}$-FliC flagellin is expressed and secreted by strain PNSS42 under swarming conditions. Lane 1, contains total extracellular $P$. stewartii protein fraction; lane 2, affinity purified $\mathrm{His}_{6}$-flagellin (predicted molecular weight of $35.6 \mathrm{kDa}$, arrow). 
we inoculated GFP-tagged bacterial strains into leaves of 14day-old corn seedlings. Active bacterial motility was only significant in the basipetal direction, with the wild-type strain DC283-GFP moving, on average, 5 to $6 \mathrm{~cm}$ from the site of inoculation after $72 \mathrm{~h}$ (Fig. 7A). This translates into approximately $4 \mathrm{~cm}$ of active movement after taking into account passive dispersion due to negative hydrostatic pressure or leaf elongation measured as a function of fluorescent microsphere infiltration into the xylem (Fig. 7A). More importantly, the $\Delta$ fliC $_{I}$ mutant strain PNSS40-GFP migrated no further than the microspheres, while the lli $_{I}$ complemented strain PNSS41GFP regained active basipetal dispersion. Statistical analysis of the data sets confirmed a significant difference in downward movement between the three strains examined. Pairwise comparison of the means using Fisher's least significant difference at a $5 \%$ level of confidence indicated that the wild-type and complemented strain are statistically indistinguishable, while both strains were statistically different from the $\Delta f_{l i} C_{I}$ mutant strain in terms of basipetal xylem dissemination.

\section{Pathogenic fitness of $\boldsymbol{P}$. stewartii requires flagella-dependent surface motility.}

The degree of virulence of the wild-type, the $\Delta f l i C_{I}$ mutant, and complemented strains was assessed by a standardized infection assay using the rating scale described by Michener (Michener et al. 2003). Seedlings were manually inoculated and rated for virulence 2 weeks postinoculation. The data summarized in Figure 7B show that the wild-type strain is virulent, with an average disease rating of 6.5 under the conditions assayed (a disease rating of 9 represents dead or near-dead plants). The disease rating for the $\Delta f_{l i} C_{I}$ mutant strain PNSS40 was 2.5, corresponding to limited spread and symptom development. The fliC $_{I}$-complemented strain PNSS41 developed symptoms corresponding to a disease rating of 4 , indicating abundant spread and symptom development.

\section{DISCUSSION}

Motility offers a survival advantage for bacteria living in natural environments. It enables them to seek out favorable surroundings or avoid unfavorable ones and compete successfully with other microbes. Surface motility plays a fundamental role in biofilm formation and, as a result, contributes significantly to the establishment of pathogenic and symbiotic bacterial interactions with higher hosts (Eberl et al. 2007; Ottemann and Miller 1997; Ramsey and Whiteley 2004; von Bodman et al. 2003). There are several reports highlighting the significance of bacterial motility in the successful establishment of such relationships in plants (Bayot and Ries 1986; Hatterman and Ries 1989; Mavrodi et al. 2006; Yao and Allen 2006). P. stewartii, the causal agent of Stewart's vascular wilt in maize, colonizes the xylem of the host by establishing cellwall-adherent biofilms and dissemination in a largely basipetal direction (Koutsoudis et al. 2006). The organism is taxonomically defined as nonmotile and nonflagellated (Pepper 1967). Our studies presented here confirm that $P$. stewartii lacks the

A
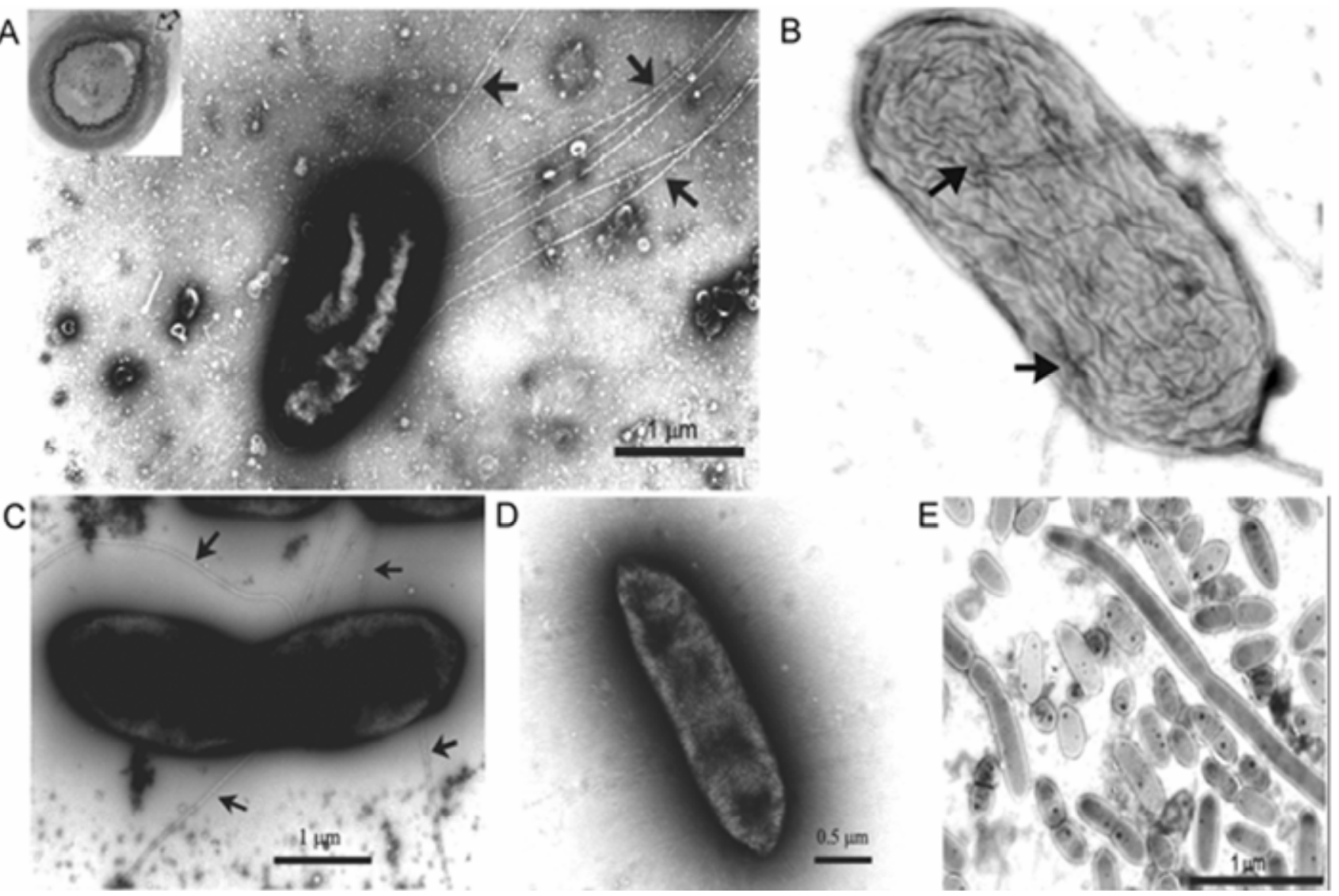

Fig. 5. Pantoea stewartii cells grown on swarming agar are flagellated. Cells taken from the edge of the swarmer colony (A, inset image, left corner) were examined by negative staining transmission electron microscopy. A, Subpopulation of the wild-type cells with thin, long flagella (arrows, inset shows flagella at higher magnification). B, Single . stewartii cell at higher magnification showing two lateral flagella emerging from the cell surface (arrows). C, Expression of $f_{l i C}$ from plasmid pCH5 in strain PNSS41 restores flagellar synthesis. D, The $\Delta f l i C_{l}$ mutant strain PNSS40 lacks flagella. E, Bacteria taken from the edge of the swarmer colony also include hyper-elongated cells interspersed with many small, dividing cells. 
ability to swim under planktonic conditions and in low-percentage agar swimming assays (data not shown) but exhibits robust flagella and EPS-dependent surface motility.

\section{Macroscopic characteristics of swarming motility.}

Swarming motility is commonly defined as a flagella-dependent form of social bacterial motility in which bacteria move in groups or "rafts" over solid surfaces. A recent review by Kaiser (2007) presents a modified, perhaps less-restrictive definition of swarming motility, suggesting that swarming is a general form of bacterial surface translocation regardless of the mechanisms that drive these motilities. Given the wide range of swarming motilities described for different bacteria, perhaps a broader definition is meaningful to accommodate such intrinsic variabilities. In $P$. stewartii, motility over semisolid agar is flagella dependent and requires the controlled synthesis of stewartan EPS. These characteristics fit the general description of swarming motility. However, the swarming behavior of $P$. stewartii differs from other systems, in that the swarming colony does not expand in a radial pattern but, rather, appears to respond to localized physicochemical stimuli that prompt a subpopulation to transition into a unidirectional vigorous motility mode. The basis for this behavior is not fully understood currently, although we have some indication that even a minor gravitational force contributes to the directionality of movement. Acidic polysaccharides such as stewartan EPS are thought to enhance the surface fluid dynamics by extracting water from the agar, thus reducing friction and aiding swarming migration (Bees et al. 2000). This could explain the movement in the direction of an incline and the observed de- crease in unidirectional motility with increasing agar concentrations. However, it is unlikely that this movement is passive as a result of EPS sliding along an incline because mutants, such as ES $\triangle I R$, produce copious amounts of EPS yet fail to move out in one direction. Other preliminary unpublished data indicate that unidirectional movement has a genetic basis with certain as yet uncharacterized insertional mutations blocking unidirectional movement. These mutants produce normal amounts of EPS.

Swarming motility is influenced by other parameters, including the type of carbon sources provided, with glucose giving the best swarming. Sodium and potassium ions inhibit this motility in $P$. stewartii. Swarming motility ceases in the presence of CCCP, which implies that it is energized by proton motive force similar to lateral flagella-mediated motility in $V$. parahaemolyticus and other bacteria (McCarter 2004).

One intriguing aspect of $P$. stewartii swarming colony differentiation is the formation of the pronounced palisade-like ring structure. The wild-type bacteria, once placed on the medium, organize into a "fence"-like assemblage comprising densely packed interconnected bacteria (M. D. Koutsoudis, unpublished observation). This developmental pattern is absent in the AHL signal synthase deficient, EPS-repressed QS mutant strain ESN51, and the esaR regulatory mutant ES $\Delta \mathrm{IR}$, suggesting that ring formation and overall swarming colony morphogenesis is governed by a defined spatiotemporal developmental regimen that relies, in part, on QS regulation. This palisade-like ring structure may provide a diffusion barrier and favor the accumulation of physiological signals such as AHL, although we have no formal proof for this concept.
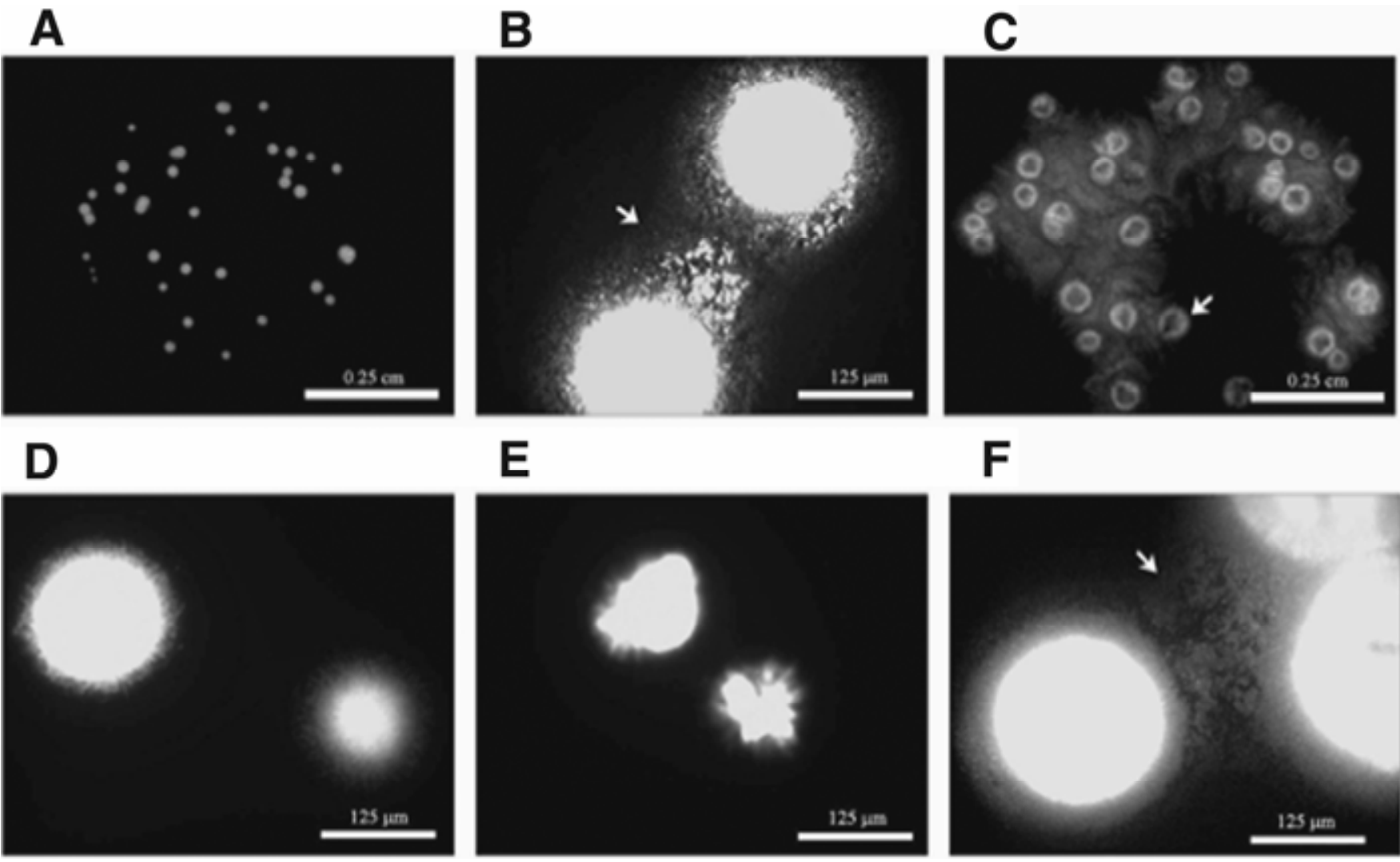

Fig. 6. FliC-dependent surface motility is important for bacterial aggregation and microcolony formation. A, Proximal, discrete bacterial colonies of green fluorescent protein-tagged bacteria grown for $24 \mathrm{~h}$ and viewed by fluorescent microscopy at low magnification; B, two colonies viewed at higher magnification show extensive bacterial migration between colonies (arrow); $\mathbf{C}$, same series of colonies shown in panel A after $48 \mathrm{~h}$ of incubation. The colonies have merged into a large conglomerate. Note the pronounced ring structures (arrow) associated with the original member colonies. D, Quorum-sensing mutant strain ESN51 (esaI::Tn5) and E, the $\Delta f_{l i C}$ mutant strain PNSS40 fail to co-migrate, while $\mathbf{F}$, the $f_{l i} C_{I}$-complemented strain PNSS41 recovers intercolony migration. 
EsaR QS represses the expression of $r c s A$, which encodes a key constituent of the Rcs phosphorelay regulatory system that is essential for stewartan EPS synthesis (Carlier and von Bodman 2006; Torres-Cabassa et al. 1987). Stewartan EPS is essential for swarming, suggesting that QS regulation of swarming motility is indirect. However, RcsA or RcsB are also involved in the direct control of the $f l h D C$ flagellar master regulatory locus in other bacteria (Clemmer and Rather 2007; Francez-Charlot et al. 2003; Wang et al. 2007). Preliminary data indicate that the integrated EsaR QS and RcsA/RcsB regulatory networks control swarming motility directly and indirectly at multiple levels (C. M. Herrera, unpublished).

\section{The $f_{l i} C_{I}$ flagellin gene is essential} for $P$. stewartii swarming motility.

In this report, we present the first experimental evidence that $P$. stewartii exhibits flagella-dependent surface motility, contrary to its current taxonomic description (Pepper 1967). Evidence for flagellar motility comes primarily from mutagenesis of the $f l i C_{I}$ gene, which is genetically linked to $f l i D$, fliT, and fliS. These four genes are part of the $\sigma^{28}$-dependent class 3 flagellar regulon described in a number of other bacteria, including E. coli and Salmonella spp. (Frye et al. 2006). Deletion of the coding region of the major $f_{l i C}$ flagellin gene impedes surface motility on semisolid swarming agar medium,

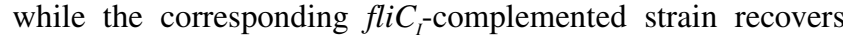
motility to near wild-type levels. Motility is restored also by in trans expression of an $\mathrm{N}$-terminal $\mathrm{His}_{6}-\mathrm{FliC}_{\mathrm{I}}$ fusion protein, demonstrating that the $\mathrm{N}$-terminal extension has no appreciable effect on the secretion, assembly, and functionality of the his ${ }_{6}-f_{l i C_{I}}$ flagellin. Motile bacteria taken directly from swarming agar plates secrete a $\mathrm{His}_{6}$-tag-specific immunodetectable protein of predicted molecular weight for the $\mathrm{His}_{6}-\mathrm{FliC}_{\mathrm{I}}$ protein. The fact that the $\mathrm{His}_{6}-\mathrm{FliC}_{\mathrm{I}}$ protein has biological activity and is found in the extracellular fraction is a strong indication for flagellar secretion and surface assembly.

TEM imaging of $P$. stewartii cells taken from the edge of the spreading colony contains a subpopulation of bacteria with long, comparatively thin flagella emerging laterally from the cells. These appendages are absent in the $\Delta f l i C_{I}$ mutant strain, and are displayed again in the corresponding fli $_{T}$-complemented strain. The $\mathrm{FliC}_{\mathrm{I}}$ protein of $P$. stewartii lacks a considerable fraction of the internal variable flagellar domain structure but features the functionally essential N-terminal and $\mathrm{C}$ terminal domains (D0 and D1) (Fig. 3B) according to a recent study by Malapaka and associates (2007) that provides detailed information about the $S$. typhimurium flagellin domain structure and organization. Specifically, the $P$. stewartii fli $C_{I}$ gene lacks the coding sequence of the entire D2b flagellin domain and specifies only partial D3 and D2a domains (Fig. 3B) (Malapaka et al. 2007). The absence of these domains has no apparent effect on $P$. stewartii FliC $_{\text {I }}$ function but offers a possible explanation for why the observed flagella are relatively thin (outer diameter 6-10 $\mathrm{nm}$ as opposed to $12-25 \mathrm{~nm}$ of the Salmonella flagellum assembled from full-length $\mathrm{fliC}$ flagellin) and fragile.
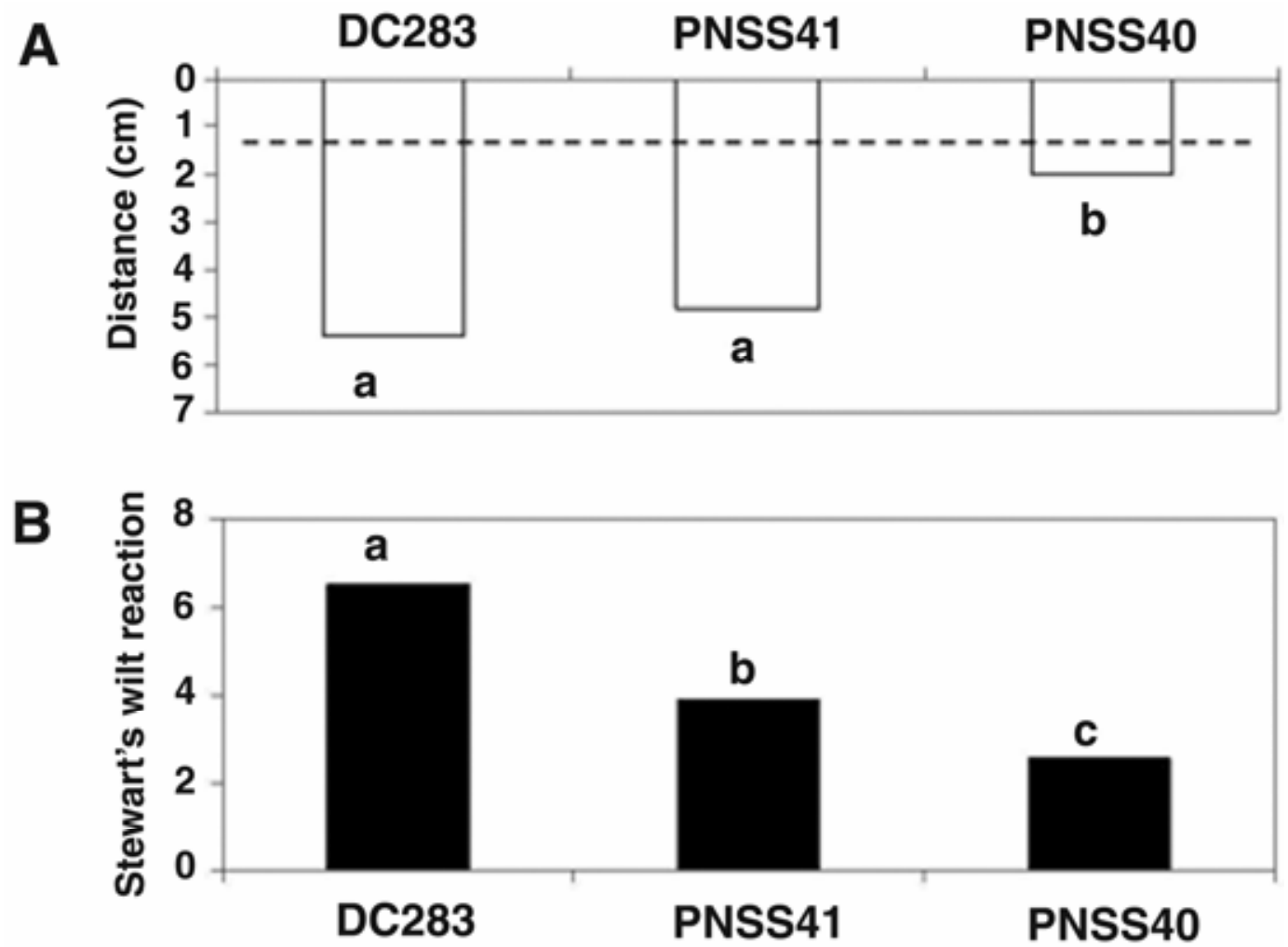

Fig. 7. Swarming motility plays a role in dissemination and virulence. A, Dissemination was assayed by inoculating approximately $10^{7}$ green fluorescent protein-tagged bacteria on sweet corn hybrid Jubilee seedling leaves and evaluated after $72 \mathrm{~h}$ of incubation. Active bacterial dissemination within the xylem of corn seedlings was assessed by epifluorescence microscopy measured against the passive infiltration of fluorescent microspheres. The wild-type strain DC283 and fli $_{I}$-complemented strain PNSS41 show significant dissemination in the basipetal (toward base of the leaves) direction, whereas the $f_{l i} C_{I}$ mutant strain PNSS40 does not move significantly beyond the passive infiltration distance of the fluorescent microspheres. Each statistical mean represents 18 replications. Dashed line indicates passive dispersion of the fluorescence microspheres. B, Virulence assays. Approx. $10^{7} \mathrm{CFU}_{\mathrm{H}}$ were inoculated into the leaves of 14-day-old sweet corn seedlings and assayed 14 days postinoculation. Symptoms were rated on a scale from 1 to 9 as described by Michener and associates (2003). The wild-type strain showed normal virulence, whereas the $\Delta f l i C_{I}$ mutant strain showed diminished disease symptoms (disease rating of 2 ). The complemented strain showed intermediary levels of virulence (disease rating of 4 ). The data presented are the mean of 15 replications; the letter designations indicate significant differences $(P<0.05)$ between treatments. 
TEM also revealed that cells taken from the vigorous motility sector of the swarmer colony contain a mixture of cell morphotypes. In addition to flagellated cells, one can observe elongated cells that are not obviously hyperflagellated as in E. coli, Salmonella spp. (Harshey and Matsuyama 1994), and other bacteria (Belas et al. 1991; Eberl et al. 1999; Kearns and Losick 2003). There are also many small, nonflagellated cells that are often binucleoid. Together, these observations suggest that swarming motility of $P$. stewartii as depicted in Figure 1 involves complex, spatiotemporally regulated biological processes that involve ring differentiation, flagellar synthesis, EPS synthesis, and, possibly, gravity and cell division.

\section{Surface swarming motility promotes bacterial aggregation.}

Flagella-driven motility may serve different functions during bacterial biofilm development, ranging from searching for suitable surfaces to establishing initial contact, mediating bacterial consolidation and microcolony formation, and facilitating bacterial dispersion from mature biofilms (Dow et al. 2003; O'Toole and Kolter 1998; Van Houdt et al. 2005). The images displayed in Figure 6 show that GFP-tagged bacteria associated with discrete but closely spaced colonies engage in intercolony migration that, over time, leads to the formation of bacterial aggregates or microcolonies (Fig. 6). Intercolony migration is completely blocked in the AHL-deficient strain ESN51 and the $\Delta f l i C_{I}$ mutant strain PNSS40. Thus, FliC-dependent surface motility has an important role in the formation of microcolonies. We have previously reported that the QS mutant strain ESN51 appears to be arrested in the surface adhesion phase of biofilm development (Koutsoudis et al. 2006). The work reported here provides further support for this assumption, showing that QS-regulated EPS production in addition to FliC flagellar synthesis enable surface adherent bacteria to consolidate into microcolonies.

\section{Swarming motility plays a role in pathogenicity.}

The plant inoculation and dissemination assays showed that the $\Delta f l i C_{I}$ mutant strain significantly attenuated the rate of basipetal xylem dissemination and overall virulence. Basipetal bacterial dissemination has been observed in other xylemcolonizing plant pathogens such as Xylella fastidiosa and $\mathrm{Er}$ winia amylovora (Bogs et al. 1998). However, in these species, xylem colonization is attributed to type IV pili-mediated motility (Meng et al. 2005).

In summary, it is evident that $P$. stewartii requires surface motility to form bacterial aggregates as a key step in bacterial biofilm development. The bacteria colonize the xylem of corn as surface-adherent biofilms. Considering that surface motility is an integral part of biofilm formation, it is not unexpected to find that a $\mathrm{fliC}_{I}$ mutant of $P$. stewartii is attenuated for virulence. Most importantly, this report emphasizes the importance of viewing bacteria as surface-adherent multicellular entities that follow a well-defined developmental regimen guided by transient, phase-specific gene expression when growing under natural conditions. It follows that important functions such as motility may well go unnoticed when studying bacterial processes exclusively under planktonic laboratory conditions.

\section{MATERIALS AND METHODS}

Strains and growth conditions.

All relevant strains are listed in Table 1 . The P. stewartii subsp. stewartii (PNSS) strains were grown on nutrient agar (NA) (Difco Laboratories, Detroit) or in Luria-Bertani broth (LB) (Difco Laboratories) or AB minimal medium (Clark and Maaloe 1967) at $28^{\circ} \mathrm{C}$ in the presence of antibiotics of nalidixic acid $\left(30 \mu \mathrm{g} \mathrm{ml}^{-1}\right)$, gentamicin $\left(10 \mu \mathrm{g} \mathrm{ml}^{-1}\right)$, streptomycin $\left(30 \mu \mathrm{g} \mathrm{ml}^{-1}\right)$, tetracycline $\left(10 \mu \mathrm{g} \mathrm{ml}^{-1}\right)$, or ampicillin $\left(100 \mu \mathrm{g} \mathrm{ml}^{-1}\right)$ where applicable. Escherichia coli strains were grown at $37^{\circ} \mathrm{C}$ on NA or LB in the presence of appropriate antibiotics: ampicillin $\left(100 \mu \mathrm{g} \mathrm{ml}^{-1}\right)$, streptomycin $\left(25 \mu \mathrm{g} \mathrm{ml}^{-1}\right)$, and kanamycin $\left(25 \mu \mathrm{g} \mathrm{ml^{-1 }}\right)$. E. coli $\mathrm{DH} 5-\alpha \mathrm{T}^{\mathrm{R}}$ was used as cloning host; strain S17-1 served as a donor for conjugal transfer of RK2-based plasmid constructs into P. stewartii strains, and strain BL21(DE3) (Novagen, Madison, WI, U.S.A.) served as a protein expression host.

Table 1. Bacterial strains and plasmids used in this study

\begin{tabular}{|c|c|c|}
\hline Strain, plasmid & Relevant characteristics $^{\text {a }}$ & Reference or source \\
\hline \multicolumn{3}{|l|}{ Escherichia coli } \\
\hline DH5- $\alpha \mathrm{T} 1^{\mathrm{R}}$ & 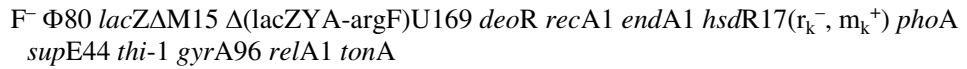 & Invitrogen, Carlsbad, CA \\
\hline S17-1 $\lambda$ pir & RP4 Mob+ & Simon et al. 1982 \\
\hline BL21(DE3) & $\mathrm{F}^{-}, d c m$ omp $\mathrm{T} h s d\left(\mathrm{r}_{\mathrm{B}}^{-}, \mathrm{m}_{\mathrm{B}}^{-}\right) \operatorname{gal\lambda }(\mathrm{DE} 3)$ & Novagen, Madison, WI \\
\hline \multicolumn{3}{|l|}{ Pantoea stewartii } \\
\hline DC283 & $\mathrm{SS} 104 \mathrm{Nal}^{\mathrm{r}}$ & Coplin et al. 1986 \\
\hline ESN51 & DC283 (esaI::Tn5seqN51), $\mathrm{Nal}^{\mathrm{r}}, \mathrm{Km}^{\mathrm{r}}, \mathrm{Gm}^{\mathrm{r}}$ & Beck von Bodman and Farrand 1995 \\
\hline $\mathrm{ES} \Delta \mathrm{IR}$ & DC283 $\Delta\left(\right.$ esaI-esaR), $\mathrm{Nal}^{\mathrm{r}}$ & Beck von Bodman and Farrand 1995 \\
\hline PNSS40 & DC283, $\Delta f l i C:: g m, \mathrm{Nal}^{\mathrm{r}}, \mathrm{Gm}^{\mathrm{r}}$ & This study \\
\hline PNSS41 & PNSS40 (pCH5), $\mathrm{Nal}^{\mathrm{r}}, \mathrm{Gm}^{\mathrm{r}}, \mathrm{Ap}^{\mathrm{r}}$ & This study \\
\hline PNSS42 & PNSS40 (pCH7), $\mathrm{Nal}^{\mathrm{r}}, \mathrm{Gm}^{\mathrm{r}}, \mathrm{Ap}^{\mathrm{r}}$ & This study \\
\hline \multicolumn{3}{|l|}{ Plasmids } \\
\hline pBluescript-II KS+ & Cloning vector, $l a c Z^{\prime}, \mathrm{Ap}^{\mathrm{r}}$ & Stratagene \\
\hline pKNG101 & Suicide vector, $R 6$ Kori, $s a c B, \mathrm{Sm}^{\mathrm{r}}$ & Kaniga et al. 1991 \\
\hline pBBR1-MCS4 & Broad host range vector, $\mathrm{Ap}^{\mathrm{r}}$ & Kovach et al. 1995 \\
\hline $\mathrm{pET} 28 \mathrm{~b}$ & Expression vector, $\mathrm{T} 7 \mathrm{Lac}$ promoter $\mathrm{Km}^{\mathrm{r}}$ & Novagen, Madison, WI \\
\hline pCR2.1 TOPO & TA cloning vector, $\mathrm{Ap}^{\mathrm{r}}, \mathrm{Km}^{\mathrm{r}}$ & Invitrogen, Carlsbad, CA \\
\hline pCR4Blunt-TOPO & Blunt end cloning vector, $\mathrm{Ap}^{\mathrm{r}}, \mathrm{Km}^{\mathrm{r}}$ & Invitrogen, Carlsbad, CA \\
\hline $\mathrm{pHC} 60$ & Broad host range vector carrying $g f p$, Tet $^{\mathrm{r}}$ & Cheng and Walker 1998 \\
\hline pMGm & aacC1 gene encoding $\mathrm{Gm}^{\mathrm{r}}$ & Murillo et al. 1994 \\
\hline pCH1 & 1.8-kb Bam HI fragment containing fliC cloned in pBluescript-II KS+ & This study \\
\hline $\mathrm{pCH} 2$ & 2.0-kb smaI Gm cassette ligated to a blunt-end 4.1-kb fragment (pCH1) & This study \\
\hline $\mathrm{pCH} 3$ & 3.1-kb SpeI/ApaI containing $\bullet$ fliC::gm from $\mathrm{pCH} 2$ cloned into $\mathrm{pKGN} 101$ & This study \\
\hline $\mathrm{pCH} 4$ & 1.3-kb fragment carrying fliC cloned into pCR2.1 TOPO & This study \\
\hline $\mathrm{pCH} 5$ & 1.1-kb EcoRI fragment carrying fliC from $\mathrm{pCH} 4$ cloned into $\mathrm{pBBR} 1-\mathrm{MCS} 4$ & This study \\
\hline pCH6 & 0.9-kb Bam HI/EcoRI fragment containing fliC cloned into pET28b & This study \\
\hline $\mathrm{pCH} 7$ & 1.0-kb XbaI/SstI digested his $_{6}:$ fliC from pCH6 cloned into pBBR1-MCS4 & This study \\
\hline
\end{tabular}

${ }^{\text {a }}$ Resistance to: $\mathrm{Ap}^{\mathrm{r}}$, ampicillin; $\mathrm{Km}^{\mathrm{r}}$, kanamycin; $\mathrm{Nal}^{\mathrm{r}}$, nalidixic acid; $\mathrm{Sm}^{\mathrm{r}}$, streptomycin; $\mathrm{Gm}^{\mathrm{r}}$, gentamicin; and $\mathrm{Tet}^{\mathrm{r}}$, tetracycline. 


\section{Standard DNA methods.}

Genomic DNA was extracted with a MasterPure DNA purification kit (Epicentre Biotechnologies, Madison, WI, U.S.A.). Plasmid DNA was purified with a QIAprep spin miniprep kit (Qiagen, Valencia, CA, U.S.A.). DNA fragments were amplified using PfuTurbo Hot Start DNA polymerase (Stratagene, La Jolla, CA, U.S.A.) or Takara Ex-Taq DNA polymerase (Takara Bio USA, Madison, WI, U.S.A.). Synthetic oligonucleotide primers were ordered to specification from Operon Biotechnologies Inc. (Huntsville, AL, U.S.A.). All restriction enzymes were purchased from Invitrogen (Carlsbad, CA, U.S.A.).

\section{Construction of a $\mathrm{fliC}_{I}$ deletion mutant.}

The $f_{l i C}$ coding region and approximately 450 bp of flanking DNA was amplified using primers FliC1-F and FliC1-R (Table 2). The resulting 1.8-kb amplicon was digested with BamHI restriction enzyme and ligated into the BamHI cloning site of pBluescriptII KS+ with the aid of T4-DNA Ligase (Invitrogen). The resulting plasmid, designated $\mathrm{pCH} 1$, served as a substrate for a second PfuTurbo DNA polymerase-specific polymerase chain reaction (PCR) amplification, using primers FliC2-F and FliC2-R (Table 2). These primers are complementary to regions within the $\mathrm{N}$-terminal and $\mathrm{C}$-terminal region of the $f_{i l} C_{I}$ coding sequence. Divergent PCR amplification yielded a 4.1-kb DNA fragment which was ligated to a gentamicin-resistant cassette obtained by SmaIspecific digestion of plasmid pMGm (Murillo et al. 1994) to yield the recombinant plasmid $\mathrm{pCH} 2$. Double digestions of pCH2 with SpeI/ApaI released a 3.1-kb fragment containing the $\Delta$ fli $_{I}: \because G m$ allele that was transferred into the suicide vector pKNG101 (Kaniga et al. 1991) to yield plasmid $\mathrm{pCH} 3$. This plasmid served a as source for creating an $\mathrm{fli}_{I}$ mutant by gene replacement after $E$. coli S17-1-mediated conjugal transfer into the wild-type strain DC283. Allelic replacement events were selected on the basis of gentamicin resistance and sucrose sensitivity. Single-copy insertions were confirmed by Southern hybridization (Sambrook et al. 1989) using a gentamicin resistance cassette-specific, biotinylated DNA probe that was created with reagents provided in the DIG DNA Labeling and Detection kit (Roche, Indianapolis, IN, U.S.A.).

\section{Creation of an $\mathrm{fliC}_{I}$ construct for complementation analysis.}

The wild-type fliC $_{I}$ gene (coding sequence and $5^{\prime}$ and $3^{\prime}$ flanking regions) was amplified by Takara Ex-Taq DNA polymerase-specific PCR using primers FliC3-F and FliC3-R (Table 2). The resulting $1.3-\mathrm{kb}$ amplicon was cloned into plasmid pCR2.1 TOPO to yield plasmid pCH4. Digestion of pCH4 with EcoRI released a 1.1-kb DNA fragment that was ligated into the broad-host-range vector plasmid pBBR1MCS4 (Kovach et al. 1995) yielding plasmid pCH5. An Nterminal $h i s_{6}$-tag: $: f_{l i C_{I}}$ fusion gene was constructed by PCR amplification of the fliC $_{I}$ gene using primers FliC4-F and FliC4-R (Table 2). The amplified 0.9-kb DNA was digested with BamHI and EcoRI for cloning into the pET28b expression vector (Novagen) yielding plasmid pCH6. Pairwise

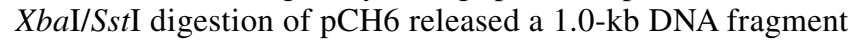
encoding the N-terminal his -tag: $_{6}$ fliC fusion gene that was ligated into plasmid pBBR1-MCS4, giving rise to plasmid pCH7. This cloning strategy places the his ${ }_{6}$-tag::fliC gene fusion under expression of the lac promoter provided by the host plasmid. Verification of the correct inserts was carried out by restriction digestion and DNA sequencing using primers T7-F or T7-R (Table 2) (Keck Sequencing Center, Yale University, New Haven, CT, U.S.A.). Plasmids pBBR1MCS4, pCH5, and pCH7 were transferred into the fliC mutant strains using E. coli S17-1.
N-terminal His $_{6}-$ FliC $_{\text {I }}$ fusion protein expression and purification.

His $_{6}-$ FliC $_{I}$ fusion protein was expressed in the E. coli BL21(DE3) by induction with IPTG (Sambrook et al. 1989). Purification of the $\mathrm{N}$-terminal $\mathrm{His}_{6}-\mathrm{FliC}_{\mathrm{I}}$ fusion protein was performed under denaturing conditions using Ni-NTA HisBind resin following recommended protocols (Novagen).

\section{Verification of flagellin synthesis in $\boldsymbol{P}$. stewartii.}

P. stewartii PNSS42 ( $\triangle$ fli $C_{I}$ chromosomal background plus in trans expression of $\mathrm{his}_{6}-\mathrm{fliC}_{I}$ from plasmid pCH7) was grown on agar medium under swarming conditions. The cells were harvested by flooding and gentle swirling of the swarming plate with $1 \times$ PBS buffer (Fisher Scientific, San Diego, CA, U.S.A.) and transfer of the cell suspension into a $50-\mathrm{ml}$ Corning plastic tube (Fisher Scientific). The cells were harvested by centrifugation at $5,000 \mathrm{rpm}$ for $15 \mathrm{~min}$ at $4{ }^{\circ} \mathrm{C}$ and resuspended in $1 \times \mathrm{PBS}$ and vortexed for $1 \mathrm{~min}$ to mechanically shear the flagella. Differential centrifugation yielded a flagella-enriched pellet that was resuspended in $1 \times$ PBS (Feng et al. 1990). The crude protein fraction was separated by discontinuous $10 \%$ SDS-PAGE and electrophoretically transferred to a polyvinylidene difluoride membrane (Invitrogen). Immunodetection was performed using 1:1000 dilutions of rabbit polyclonal anti 6x His-epitope tag (catalog no. PA1983A Bioreagent, ABR) as primary antibody and alkaline phosphatase-conjugated horse anti-rabbit immunoglobulin $\mathrm{G}$ as secondary antibody. Chromogenic immunodetection utilized the WesternBreeze kit (Invitrogen).

\section{Swarming motility assays.}

Cells grown in LB to a cell density of 0.5 (optical density at $\left.600 \mathrm{~nm}\left[\mathrm{OD}_{600}\right]\right)$ were harvested and washed twice in $1 \times \mathrm{PBS}$ buffer. A $2-\mu$ l volume of cell suspension containing approximately $10^{7}$ cells was transferred to the center of the swarming agar plate. A dilute inoculum containing $<50$ cells per $2-\mu 1$ inoculum volume was plated to achieve growth of discrete but closely spaced colonies. Swarming media consisted of $0.4 \%$ Difco agar (Fisher Scientific) suspended either in LB, nutrient broth, or AB minimal medium (0.1-0.4\% casamino acids). All swarming media contained $0.4 \%$ glucose as carbon source unless otherwise specified. The effects of sodium chloride $(\mathrm{NaCl})$ and potassium chloride $(\mathrm{KCl})$ on swarming motility were evaluated by adding increasing concentrations of 0 to 170 $\mathrm{mM}$. Where appropriate, agar medium was amended with 10 $\mu \mathrm{M}$ synthetic $N$ - $\beta$-ketocaproyl-L-homoserine lactone (SigmaAldrich, St. Louis), $10 \mu \mathrm{M}$ CCCP (Sigma-Aldrich), or $25 \mu \mathrm{M}$ phenamil methanesulfonate salt. Swarming plates were wrapped in Saranwrap to minimize desiccation during incubation at $28^{\circ} \mathrm{C}$. Motility was evaluated macroscopically by measuring the area of surface colonization over time, and microscopically as described below.

Table 2. Primers used in this study

\begin{tabular}{ll}
\hline Name & \multicolumn{1}{c}{ Sequences $\left(\mathbf{5}^{\prime}-\mathbf{3}^{\prime}\right)^{\mathbf{a}}$} \\
\hline FliC1-F & ATCGCGGATCCGCGTTCGTGCTGGTGACTTTCG \\
FliC1-R & TTCGCGGATCCGCGTGCCTTGCTTATCACTG \\
FliC2-F & CGGAATTCCGATACGCAGGCCAGAAGACAGG \\
FliC2-R & CGGAATTCCGAACACCGTGACCAACCTGACCG \\
FliC3-F & GCGAGTGGCAAAAGATTAGC \\
FliC3-R & GACATCCTCTGGTTGTGCAT \\
FliC4-F & TACGGGATCCTATGGCAGTGATTAACACTAACACC \\
FliC4-R & ATCCGGAATTCCTTAACGCAGCAGAGACAGCATGG \\
T7-F & TAATACGACTCACTATAGGG \\
T7-R & CTAGTTATTGCTCAGCGG \\
\hline
\end{tabular}

${ }^{a}$ Underlining indicates incorporated restriction sites for cloning (BamHI GGATCC and EcoRI GAATTC). 


\section{Microscopic methods.}

Bacteria were visualized by bright field, phase contrast, or epifluorescence using an IX70 Olympus Microscope (Olympus, Melville, NY, U.S.A.). GFP-tagged cells were observed using a fluorescence Olympus U-MWB filter cube consisting of a combination of DM500 dichroic filter, BP450-480 excitation filter, and BA515 barrier filter. Images were acquired using an S99806 MagnaFire charge-coupled device camera (Olympus, Center Valley, PA, U.S.A.). Representative images were analyzed by Jasc Paint Shop Pro 9.01 (Jasc Software Inc., Eden Prairie, MN, U.S.A.).

Electron microscopy involved the transfer of bacteria to UV treated, carbon-stabilized formvar 400-mesh copper transmission grids (Bozzola and Russel 1999). The bacteria were fixed to the grid with $0.5 \%$ glutaraldehyde in $0.1 \mathrm{M}$ PIPES buffer fixative, $\mathrm{pH}$ 7.3, and threefold washing in 0.1 M PIPES buffer. Negative staining was performed in $1 \%$ uranyl acetate for $30 \mathrm{~s}$ (Kirov et al. 2002). Grids were examined with a Philips EM300 electron microscope operating at an accelerating voltage of $80 \mathrm{KV}$.

\section{Bacterial dissemination and virulence assays.}

$P$. stewartii strains expressing the pHC60 plasmid-born GFP $_{\text {S65t }}$ gene (Cheng and Walker 1998) were evaluated for their ability to disseminate in planta. Bacterial cells were grown in $\mathrm{AB}$ minimal medium, $0.2 \%$ glucose, to $\mathrm{OD}_{600}=0.4$ and harvested by centrifugation. The pellet was washed once and resuspended in $1 \times$ PBS buffer containing $0.2 \%$ Tween 40 . An inoculum of approximately $10^{7}$ GFP-tagged cells suspended in $2 \mu \mathrm{l}$ of PBS buffer were placed across a partial vascular incision wound of seventeen-day old sweet corn seedlings (Hybrid Jubilee; Syngenta Seeds Inc, Boise, ID, U.S.A.) (Coplin and Majerczak 2002). Fluospheres (fluorescent carboxylated modified polystyrene microspheres) $0.2 \mu \mathrm{m}$ in diameter (Invitrogen-Molecular Probes, Eugene, OR, U.S.A.) were inoculated by the same method to assess passive movement (Meng et al. 2005). Inoculated plants were placed into an environmental growth chamber (EGC) model GCW15 (EGC, Chagrin Falls, OH, U.S.A.) at 28 and $25^{\circ} \mathrm{C}$ day and night, respectively, and $70 \%$ relative humidity in a 12-h light-and-dark cycle. Bacterial dissemination, measuring the distance of GFP-detectable bacterial growth within colonized xylem from the site of inoculation, was determined after $72 \mathrm{~h}$ as previously described (Koutsoudis et al. 2006).

Virulence assays were performed by inoculating approximately $10^{7}$ cells directly into the wounded stem halfway between the first and the second leaf of 14-day-old sweet corn hybrid Jubilee seedlings. Disease progression was evaluated 14 days postinoculation using the disease rating system described by (Michener et al. 2003). The data were analyzed by one-way analysis of variance using an Excel Analysis ToolPak to test differences among means, followed by Fisher's least significant difference test for means separation. Statistical significance was tested at the 5\% confidence level.

\section{ACKNOWLEDGMENTS}

We thank C. Roper for critical reading of the manuscript and A. Carlier and R. Penyalver for helpful discussions. This work was supported by grants to S. von Bodman from the United States Department of Agriculture National Research Initiative (grant 2002-35319-12637), the National Science Foundation (MCB 0211687 and MCB 0619104), and Cooperative State Research, Education, and Extension Service (CSREES) Grant CONS00775.

\section{LITERATURE CITED}

An, D., Danhorn, T., Fuqua, C., and Parsek, M. R. 2006. Quorum sensing and motility mediate interactions between Pseudomonas aeruginosa and Agrobacterium tumefaciens in biofilm cocultures. Proc. Natl. Acad. Sci. U.S.A. 103:3828-3833.

Bayot, R. G., and Ries, S. M. 1986. Role of motility in apple blossom infection by Erwinia amylovora and studies of fire blight control with attractant and repellent compounds. Phytopathology 76:441-445.

Beck von Bodman, S., and Farrand, S. K. 1995. Capsular polysaccharide biosynthesis and pathogenicity in Erwinia stewartii require induction by an N-acylhomoserine lactone autoinducer. J. Bacteriol. 177:50005008

Bees, M. A., Andresen, P., Mosekilde, E., and Givskov, M. 2000. The interaction of thin-film flow, bacterial swarming and cell differentiation in colonies of Serratia liquefaciens. J. Math. Biol. 40:27-63.

Belas, R., Erskine, D., and Flaherty, D. 1991. Proteus mirabilis mutants defective in swarmer cell differentiation and multicellular behavior. J. Bacteriol. 173:6279-6288.

Beloin, C., and Ghigo, J. M. 2004. Finding gene-expression patterns in bacterial biofilms. Trends Microbiol. 13:16-19.

Bernhard, F., Coplin, D. L., and Geider, K. 1993. A gene cluster for amylovoran synthesis in Erwinia amylovora: Characterization and relationship to cps genes in Erwinia stewartii. Mol. Gen. Genet. 239:158-168.

Bogs, J., Bruchmüller, I., Erbar, C., and Geider, K. 1998. Colonization of host plants by fire blight pathogen Erwinia amylovora marked with genes for bioluminescence and fluorescence. Phytopathology 88:418-421.

Bohm, M., Hurek, T., and Reinhold-Hurek, B. 2007. Twitching motility is essential for endophytic rice colonization by the N2-fixing endophyte Azoarcus sp. strain BH72. Mol. Plant-Microbe Interact. 20:526-533.

Boles, B. R., and McCarter, L. L. 2000. Insertional inactivation of genes encoding components of the sodium-type flagellar motor and switch of Vibrio parahaemolyticus. J. Bacteriol. 182:1035-1045.

Bozzola, J., and Russel, L. D. 1999. Electron Microscopy. Principles and Techniques for Biologist, 2nd ed. Jones and Barlett Publishers, Inc., Sudbury, MA, U.S.A.

Braeken, K., Daniels, R., Vos, K., Fauvart, M., Bachaspatimayum, D., Vanderleyden, J., and Michiels, J. 2007. Genetic determinants of swarming in Rhizobium etli. Microb. Ecol. 55:54-64.

Braun, E. J. 1982. Ultraestructural investigation of resistant and susceptible maize inbred infected with Erwinia stewartii. Phytopathology 72:159-166.

Carlier, A. L., and von Bodman, S. B. 2006. The rcsA promoter of Pantoea stewartii subsp. stewartii features a low-level constitutive promoter and an EsaR quorum-sensing-regulated promoter. J. Bacteriol. 188:45814584.

Cheng, H. P., and Walker, G. C. 1998. Succinoglycan is required for initiation and elongation of infection threads during nodulation of alfalfa by Rhizobium meliloti. J. Bacteriol. 180:5183-5191.

Chilcott, G. S., and Hughes, K. T. 2000. Coupling of flagellar gene expression to flagellar assembly in Salmonella enterica serovar Typhimurium and Escherichia coli. Microbiol. Mol. Biol. Rev. 64:694-708.

Clark, J. D., and Maaloe, O. 1967. DNA replication and the cell division cycle in Escherichia coli. J. Mol. Biol. 23:99-112.

Clemmer, K. M., and Rather, P. N. 2007. Regulation of flhDC expression in Proteus mirabilis. Res. Microbiol. 158:295-302.

Coplin, D. L., and Majerczak, D. R. 2002. Identification of Pantoea stewartii subsp. stewartii by PCR and strain differentiation by PFGE. Plant Dis. 86:304-311.

Coplin, D. L., Frederick, R. D., Majerczak, D. R., and Haas, E. S. 1986. Molecular cloning of virulence genes from Erwinia stewartii. J. Bacteriol. 168:619-623.

Danhorn, T., and Fuqua, C. 2007. Biofilm formation by plant-associated bacteria. Annu. Rev. Microbiol. 61:401-422.

Dolph, P. J., Majerczak, D. R., and Coplin, D. L. 1988. Characterization of a gene cluster for exopolysaccharide biosynthesis and virulence in $\mathrm{Er}$ winia stewartii. J. Bacteriol. 170:865-871.

Dow, J. M., Crossman, L., Findlay, K., He, Y. Q., Feng, J. X., and Tang, J. L. 2003. Biofilm dispersal in Xanthomonas campestris is controlled by cell-cell signaling and is required for full virulence to plants. Proc. Natl. Acad. Sci. U. S. A. 100:10995-11000.

Eberl, L., Molin, S., and Givskov, M. 1999. Surface motility of Serratia liquefaciens MG1. J. Bacteriol. 181:1703-1712.

Eberl, L., von Bodman, S. B., and C. Fuqua. 2007. Biofilm on plant surfaces. In: The Biofilm Mode of Life: Mechanism and Adaptation. S. K. Kjelleberg and Michael Givskov, eds. Horizon Bioscience, Lyngby, Denmark.

Feng, P., Sugasawara, R. J., and Schantz, A. 1990. Identification of a common enterobacterial flagellin epitope with a monoclonal antibody. J. Gen. Microbiol. 136:337-342.

Francez-Charlot, A., Laugel, B., Van Gemert, A., Dubarry, N., Wiorowski, F., Castanie-Cornet, M. P., Gutierrez, C., and Cam, K. 2003. RcsCDB His-Asp phosphorelay system negatively regulates the $f l h D C$ operon in Escherichia coli. Mol. Microbiol. 49:823-832. 
Frederick, R. D., Ahmad, M., Majerczak, D. R., Arroyo-Rodriguez, A. S., Manulis, S., and Coplin, D. L. 2001. Genetic organization of the Pantoea stewartii subsp. stewartii hrp gene cluster and sequence analysis of the $h r p A, h r p C, h r p N$, and $w t s E$ operons. Mol. Plant-Microbe Interact. 14:1213-1222.

Frye, J., Karlinsey, J. E., Felise, H. R., Marzolf, B., Dowidar, N., McClelland, M., and Hughes, K. T. 2006. Identification of new flagellar genes of Salmonella enterica serovar Typhimurium. J. Bacteriol. 188:2233-2243

Fujishige, N. A., Kapadia, N. N., De Hoff, P. L., and Hirsch, A. M. 2006 Investigations of Rhizobium biofilm formation. FEMS (Fed. Eur. Microbiol. Soc.) Microbiol. Ecol. 56:195-206.

Fuqua, C., Parsek, M. R., and Greenberg, E. P. 2001. Regulation of gene expression by cell-to-cell communication: Acyl-homoserine lactone quorum sensing. Annu. Rev. Genet. 35:439-468.

Gardel, C. L., and Mekalanos, J. J. 1996. Alterations in Vibrio cholerae motility phenotypes correlate with changes in virulence factor expression. Infect. Immun. 64:2246-2255.

Glasner, J. D., Liss, P., Plunkett, G., 3rd, Darling, A., Prasad, T., Rusch, M., Byrnes, A., Gilson, M., Biehl, B., Blattner, F. R., and Perna, N. T. 2003. ASAP, a systematic annotation package for community analysis of genomes. Nucleic Acids Res. 31:147-151.

Glasner, J. D., Rusch, M., Liss, P., Plunkett, G., 3rd, Cabot, E. L., Darling, A., Anderson, B. D., Infield-Harm, P., Gilson, M. C., and Perna, N. T. 2006. ASAP, a resource for annotating, curating, comparing, and disseminating genomic data. Nucleic Acids Res. 34:D41-D45.

Hall-Stoodley, L., and Stoodley, P. 2005. Biofilm formation and dispersal and the transmission of human pathogens. Trends Microbiol. 13:7-10.

Hall-Stoodley, L., Costerton, J. W., and Stoodley, P. 2004. Bacterial biofilms: From the natural environment to infectious diseases. Nat. Rev. Microbiol. 2:95-108.

Ham, J. H., Majerczak, D. R., Arroyo-Rodriguez, A. S., Mackey, D. M., and Coplin, D. L. 2006. WtsE, an AvrE-family effector protein from Pantoea stewartii subsp. stewartii, causes disease-associated cell death in corn and requires a chaperone protein for stability. Mol. PlantMicrobe Interact. 19:1092-1102.

Hammer, B. K., and Bassler, B. L. 2003. Quorum sensing controls biofilm formation in Vibrio cholerae. Mol. Microbiol. 50:101-104.

Harshey, R. M. 2003. Bacterial motility on a surface: Many ways to a common goal. Annu. Rev. Microbiol. 57:249-273.

Harshey, R. M., and Matsuyama, T. 1994. Dimorphic transition in Escherichia coli and Salmonella typhimurium: Surface-induced differentiation into hyperflagellate swarmer cells. Proc. Natl. Acad. Sci. U.S.A. 91:8631-8635.

Hatterman, D. R., and Ries, S. M. 1989. Motility of Pseudomonas syringae pv. glycinea and its role in infection. Phytopathology 79:284-289.

Kaiser, D. 2007. Bacterial swarming: A re-examination of cell-movement patterns. Curr. Biol. 17:R561-R570.

Kang, Y., Liu, H., Genin, S., Schell, M. A., and Denny, T. P. 2002. Ralstonia solanacearum requires type 4 pili to adhere to multiple surfaces and for natural transformation and virulence. Mol. Microbiol. 46:427-437.

Kaniga, K., Delor, I., and Cornelis, G. R. 1991. A wide-host-range suicide vector for improving reverse genetics in gram-negative bacteria: Inactivation of the blaA gene of Yersinia enterocolitica. Gene 109:137-141.

Kearns, D. B., and Losick, R. 2003. Swarming motility in undomesticated Bacillus subtilis. Mol. Microbiol. 49:581-590.

Kim, J., Kang, Y., Choi, O., Jeong, Y., Jeong, J. E., Lim, J. Y., Kim, M., Moon, J. S., Suga, H., and Hwang, I. 2007. Regulation of polar flagellum genes is mediated by quorum sensing and FlhDC in Burkholderia glumae. Mol. Microbiol. 64:165-179.

Kim, W., and Surette, M. G. 2005. Prevalence of surface swarming behavior in Salmonella. J. Bacteriol. 187:6580-6583.

Kirov, S. M., Tassell, B. C., Semmler, A. B., O'Donovan, L. A., Rabaan, A. A., and Shaw, J. G. 2002. Lateral flagella and swarming motility in Aeromonas species. J. Bacteriol. 184:547-555.

Koutsoudis, M. D., Tsaltas, D., Minogue, T. D., and Von Bodman, S. B. 2006. Quorum-sensing regulation governs bacterial adhesion, biofilm development, and host colonization in Pantoea stewartii subspecies stewartii. Proc. Natl. Acad. Sci. U.S.A. 103:5983-5988.

Kovach, M. E., Elzer, P. H., Hill, D. S., Robertson, G. T., Farris, M. A., Roop, R. M., and Peterson, K. M. 1995. Four new derivatives of the broad-host-range cloning vector pBBR1MCS, carrying different antibiotic-resistance cassettes. Gene 166:175-176.

Majdalani, N., and Gottesman, S. 2005. The Rcs phosphorelay: A complex signal transduction system. Annu. Rev. Microbiol. 59:379-405.

Malapaka, R. R., Adebayo, L. O., and Tripp, B. C. 2007. A deletion variant study of the functional role of the Salmonella flagellin hypervariable domain region in motility. J. Mol. Biol. 365:1102-1116.

Mattick, J. S. 2002. Type IV pili and twitching motility. Annu. Rev. Microbiol. 56:289-314
Mavrodi, O. V., Mavrodi, D. V., Park, A. A., Weller, D. M., and Tomashow, L. S. 2006. The role of $d s b A$ in colonization of the wheat rhizosphere by Pseudomonas fluorescens Q8r1-96. Microbiology 152:863-872.

McCarter, L. L. 2001. Polar flagellar motility of the Vibrionaceae. Microbiol. Mol. Biol. Rev. 653:445-462.

McCarter, L. L. 2004. Dual flagellar systems enable motility under different circumstances. J. Mol. Microbiol. Biotechnol. 7:18-29.

Meng, Y., Li, Y., Galvani, C. D., Hao, G., Turner, J. N., Burr, T. J., and Hoch, H. C. 2005. Upstream migration of Xylella fastidiosa via pilusdriven twitching motility. J. Bacteriol. 187:5560-5567.

Mergaert, J., Verdonck, L., and Kersters, K. 1993. Transfer of Erwinia ananas (synonym, Erwinia uredovora) and Erwinia stewartii to genus Pantoea emend as Pantoea ananas (Serrano 1928) comb. nov. and Pantoea stewartii (Smith 1898) comb. nov. respectively, and description of Pantoea stewartii subsp. indologenes subsp. nov. Int. J. Syst. Bacteriol. 43:162-173.

Merritt, P. M., Danhorn, T., and Fuqua, C. 2007. Motility and chemotaxis in Agrobacterium tumefaciens surface attachment and biofilm formation. J. Bacteriol. 189:8005-8014.

Michener, P. M., Freeman, N. D., and Pataky, J. K. 2003. Relationships between reaction of sweet corn hybrids to Stewart's wilt and incidence of systemic infection by Erwinia stewartii. Plant Dis. 87:223-228.

Minogue, T. D., Wehland-von Trebra, M., Bernhard, F., and von Bodman, S. B. 2002. The autoregulatory role of EsaR, a quorum-sensing regulator in Pantoea stewartii ssp. stewartii: Evidence for a repressor function. Mol. Microbiol. 44:1625-1635.

Minogue, T. D., Carlier, A. L., Koutsoudis, M. D., and von Bodman, S. B. 2005. The cell density-dependent expression of stewartan exopolysaccharide in Pantoea stewartii ssp. stewartii is a function of EsaR-mediated repression of the $r c s A$ gene. Mol. Microbiol. 56:189-203.

Monier, J. M., and Lindow, S. E. 2003. Differential survival of solitary and aggregated bacterial cells promotes aggregate formation on leaf surfaces. Proc. Natl. Acad. Sci. U.S.A. 100:15977-15982

Murillo, J., Shen, H., Gerhold, D., Sharma, A., Cooksey, D. A., and Keen, N. T. 1994. Characterization of pPT23B, the plasmid involved in syringolide production by Pseudomonas syringae pv. tomato PT23. Plasmid 31:275-287.

Nimtz, M., Mort, A., Wray, V., Domke, T., Zhang, Y., Coplin, D. L., and Geider, K. 1996. Structure of stewartan, the capsular exopolysaccharide from the corn pathogen Erwinia stewartii. Carbohydr. Res. 288:189201.

O'Toole, G. A., and Kolter, R. 1998. Flagellar and twitching motility are necessary for Pseudomonas aeruginosa biofilm development. Mol. Microbiol. 30:295-304.

Ottemann, K. M., and Miller, J. F. 1997. Roles for motility in bacterialhost interactions. Mol. Microbiol. 24:1109-1117.

Parsek, M. R., and Greenberg, E. P. 2000. Acyl-homoserine lactone quorum sensing in gram-negative bacteria: A signaling mechanism involved in associations with higher organisms. Proc. Natl. Acad. Sci. U.S.A. 97:8789-8793.

Pataky, J. K. 2003. Stewart's wilt of corn. APSnet, American Phytopathological Society, St. Paul. MN, U.S.A. Published online.

Pepper, E. H. 1967. Stewart's bacterial wilt of corn. Monograph 4. American Phytopathological Society, St. Paul, MN, U.S.A

Quinones, B., Dulla, G., and Lindow, S. E. 2005. Quorum sensing regulates exopolysaccharide production, motility, and virulence in Pseudomonas syringae. Mol. Plant-Microbe Interact. 18:682-693.

Ramsey, M. M., and Whiteley, M. 2004. Pseudomonas aeruginosa attachment and biofilm development in dynamic environments. Mol. Microbiol. 53:1075-1087.

Rauprich, O., Matsushita, M., Weijer, C. J., Siegert, F., Esipov, S. E., and Shapiro, J. A. 1996. Periodic phenomena in Proteus mirabilis swarm colony development. J. Bacteriol. 178:6525-6538

Sambrook, J., Fritsch, E. F., and Maniatis, T. 1989. Molecular Cloning: A Laboratory Manual, 2nd ed. Cold Spring Harbor Laboratory Press, Cold Spring Harbor, NY, U.S.A

Sauer, K., Camper, A. K., Ehrlich, G. D., Costerton, J. W., and Davies, D. G. 2002. Pseudomonas aeruginosa displays multiple phenotypes during development as a biofilm. J. Bacteriol. 184:1140-1154.

Schembri, M. A., Dalsgaard, D., and Klemm, P. 2004. Capsule shields the function of short bacterial adhesins. J. Bacteriol. 186:1249-1257.

Simon, R., Priefer, U., and Pühler, A. 1982. A broad host range mobilization system for in vivo genetics engineering: Transposon mutagenesis in gram-negative bacteria. Biotechnology 1:784-769.

Tans-Kersten, J., Huang, H., and Allen, C. 2001. Ralstonia solanacearum needs motility for invasive virulence on tomato. J. Bacteriol. 183:35973605.

Torres-Cabassa, A., Gottesman, S., Frederick, R. D., Dolph, P. J., and Coplin, D. L. 1987. Control of extracellular polysaccharide synthesis in Erwinia stewartii and Escherichia coli K-12: A common regulatory 
function. J. Bacteriol. 169:4525-4531.

van Houdt, R., Moons, P., Jansen, A., Vanoirbeek, K., and Michiels, C. W. 2005. Genotypic and phenotypic characterization of a biofilm-forming Serratia plymuthica isolate from a raw vegetable processing line. FEMS (Fed. Eur. Microbiol. Soc.) Microbiol. Lett. 246:265-272.

von Bodman, S. B., Majerczak, D. R., and Coplin, D. L. 1998. A negative regulator mediates quorum-sensing control of exopolysaccharide production in Pantoea stewartii subsp. stewartii. Proc. Natl. Acad. Sci. U.S.A. 95:7687-7692.

von Bodman, S. B., Bauer, W. D., and Coplin, D. L. 2003. Quorum sensing in plant-pathogenic bacteria. Annu. Rev. Phytopathol. 41:455-482.

Wang, Q., Zhao, Y., McClelland, M., and Harshey, R. M. 2007. The RcsCDB signaling system and swarming motility in Salmonella enterica serovar Typhimurium: Dual regulation of flagellar and SPI-2 virulence genes. J. Bacteriol. 189:8447-8457.

Wang, X., Rochon, M., Lamprokostopoulou, A., Lunsdorf, H., Nimtz, M., and Romling, U. 2006. Impact of biofilm matrix components on inter- action of commensal Escherichia coli with the gastrointestinal cell line HT-29. Cell Mol. Life Sci. 63:2352-2363.

Whiteley, M., Bangera, M. G., Bumgarner, R. E., Parsek, M. R., Teitzel, G. M., Lory, S., and Greenberg, E. P. 2001. Gene expression in Pseudomonas aeruginosa biofilms. Nature 413:860-864.

Yao, J., and Allen, C. 2006. Chemotaxis is required for virulence and competitive fitness of the bacterial wilt pathogen Ralstonia solanacearum. J. Bacteriol. 188:3697-3708

Yao, J., and Allen, C. 2007. The plant pathogen Ralstonia solanacearum needs aerotaxis for normal biofilm formation and interactions with its tomato host. J. Bacteriol. 189:6415-6424.

AUTHOR-RECOMMENDED INTERNET RESOURCE

University of Wisconsin-Madison ASAP (a systemic annotation package for community analysis of genome) database:

asap.ahabs.wisc.edu/asap/home.php 